\title{
Modified a Colony Forming Unit Microbial Adherence to Hydrocarbons Assay and Evaluated Cell Surface Hydrophobicity and Biofilm Production of Vibrio scophthalmi
}

\section{Guo Qiao ${ }^{1,4}$, Hua Lí ${ }^{2}$ De-Hai Xü and Soo II Park ${ }^{1 *}$}

${ }^{1}$ Department of Aquatic Life Medicine, Pukyong National University, Busan 608737, Republic of Korea

${ }^{2}$ Key Laboratory of Mariculture \& Biotechnology, Agriculture Ministry, PRC, Dalian Ocean University, Dalian 116023, Liaoning Province, China

${ }^{3}$ US Department of Agriculture, Agricultural Research Service, Aquatic Animal Health Research Unit, 990 Wire Road, Auburn, AL 36832, USA

${ }^{4}$ West Sea Fisheries Research Institute, National Fisheries Research \& Development Institute, Chungnam 357945, Republic of Korea

\begin{abstract}
Vibrio scophthalmi has been considered as an opportunistic pathogen of the flat fish. There is little information available on V. scophthalmi adhesion to the host, an important step in the initial infection process. The objectives of this study were to (1) develop a modified Microbial Adherence to Hydrocarbons (MATH) assay using Colony Forming Unit (CFU) method and evaluate the cell surface hydrophobicity of $\mathrm{V}$. scophthalmi, (2) detect slime layer and biofilm production of $V$. scophthalmi and (3) investigate the motility and antibiotic susceptibility associated with biofilm production of $V$. scophthalmi. The results showed that cell surface hydrophobicity of $V$. scophthalmi was moderate by Salt Aggregation Test (SAT) and MATH assay. The fraction partitioned to the hydrocarbon phase (\%Adh) was determined significantly higher by modified CFU MATH assay than that by classical spectrophotometer MATH assay and microscope MATH assay. V. scophthalmi produced slime layer and biofilm. The optimal biofilm production conditions for $V$. scophthalmi were: BHIB media or TSB supplemented with $2 \% \mathrm{NaCl}$ and $0-0.5 \%$ glucose and incubation for $24 \mathrm{~h}$. The level of biofilm production is related with the pathogenicity of $V$. scophthalmi and antibiotics susceptibility. $V$. scophthalmi was motile with flagellum-mediated swimming and type IV pilus-mediated twitching, but no swarming.
\end{abstract}

Keywords: Vibrio scophthalmi; Cell surface hydrophobicity; Biofilm production

\section{Introduction}

Vibrio scophthalmi has been found widely in sea water and in many marine fish, such as common dentex (Dentex dentex L.) $[1,2]$, olive flounder (Paralichthys olivaceus) [3] and turbot (Scophthalmimus maximus) [4]. V. scophthalmi is an opportunistic pathogen of flat fish, primarily infecting olive flounder and turbot $[2,5]$. There is little information available on the virulence factors of V. scophthalmi, such as adhesion to the host, survival ability in fish serum and skin mucus and extracellular proteins.

Microbial adhesion to surfaces is an important step in the initial infection process [6]. Cell surface hydrophobicity and cell surface charge of bacteria have been recognized as measurable physicochemical variables for evaluating the attachment of bacteria to host cells $[7,8]$. The hydrophobic cell surface may provide advantageous associating sites to bacteria in vivo by increasing resistance to phagocytosis or favoring colonization in tissues of the host. A variety of techniques are applied to evaluate the cell surface hydrophobicity. The Salt Aggregation Test (SAT) uses a salting-out agent to induce aggregation of cells for determining bacterial cell surface hydrophobicity [9]. Another commonly used technique is the Microbial Adherence to Hydrocarbons (MATH), previously called BATH (Bacterial Adherence to Hydrocarbons) by Rosenberg et al. [10]. The MATH protocol involves vortexing bacterial suspension in the presence of liquid hydrocarbon. During this process, the hydrocarbon breaks up into small droplets. Some microorganisms adhere to the droplets and then rise with the hydrocarbon droplet during droplet coalescence and phase segregation. The fraction of adhering microorganisms is evaluated by comparing the initial and final absorbance values of the aqueous microbial suspension. MATH can measure complicated interplay of long-range vander Waals, electrostatic forces and various short-range interactions [11]. Although the classical MATH assay is widely used, it correlates poorly with other hydropho- bicity assays [12]. Recently, Zoueki et al. [13] developed a modified microscope MATH assay instead of the classical MATH assay. It can reduce the negative effect associated with the presence of oil droplets in the aqueous suspension in the classical MATH assay. In the modified microscope MATH assay, microscopic examination of the aqueous suspension and direct cell counts provides cell concentrations that are free of interference from hydrocarbon droplets [13]. However, the assay is time consuming and assay results are sometimes influenced by the bacteria which moved quickly under microscope. To avoid inaccurate enumeration in the microscope MATH assay, a more accurate and time saving assay is needed for determination of hydrophobicity. The objective of this study was to develop a modified MATH assay using Colony Forming Unit (CFU) method and evaluate the cell surface hydrophobicity of $V$. scophthalmi through SAT and MATH assays. In addition, biofilm is a determining factor in the adhesive process and survival of pathogens in cells [14]. A second objective of this study was to evaluate slime layer and biofilm production of $V$. scophthalmi. Ultimately, the study was conducted to investigate the motility and antibiotic susceptibility associated with bioflim production of V. scophthalmi.

*Corresponding author: Soo II Park, Department of Aquatic Life Medicine Pukyong National University, Busan 608737, Republic of Korea, Tel: +82 51629 5939; Fax: +82 51629 5938; E-mail: parksi@pknu.ac.kr

Received January 19, 2012; Accepted February 14, 2012; Published February 20, 2012

Citation: Qiao G, Li H, Xu DH, II Park S (2012) Modified a Colony Forming Unit Microbial Adherence to Hydrocarbons Assay and Evaluated Cell Surface Hydrophobicity and Biofilm Production of Vibrio scophthalmi. J Bacteriol Parasito 3:130 doi:10.4172/2155-9597.1000130

Copyright: ( 2012 Qiao G, et al. This is an open-access article distributed unde the terms of the Creative Commons Attribution License, which permits unrestricted use, distribution, and reproduction in any medium, provided the original author and source are credited. 
Citation: Qiao G, Li H, Xu DH, II Park S (2012) Modified a Colony Forming Unit Microbial Adherence to Hydrocarbons Assay and Evaluated Cell Surface Hydrophobicity and Biofilm Production of Vibrio scophthalmi. J Bacteriol Parasitol 3:130 doi:10.4172/2155-9597.1000130

Page 2 of 6

\section{Materials and Methods}

\section{Bacterial strains and culture media}

Two strains A19008 and A19010 were isolated from kidney and spleen of cultured diseased olive flounder using Tryptic Soy Agar (TSA) supplemented with $2 \% \mathrm{NaCl}$ (ST) and Thiosulfate-Citrate-Bile-Sucrose (TCBS) at $27^{\circ} \mathrm{C}$ and preserved under $-80^{\circ} \mathrm{C}$ at the Fish Disease and Prevention Laboratory, Pukyong National University, Korea. These 2 strains were identified as $V$. scophthalmi according to phenotypic characteristics, 16S rRNA and DNAJ gene sequences analysis in our previous study. Other reference strains $V$. scophthalmi CECT 4638 (strain A089), V. scophthalmi CAIM 1797 and Escherichia coli JM089 (ATCC 29522) were used as controls in this study. Bacteria were routinely grown in Tryptic Soy Broth (TSB) or ST at $27^{\circ} \mathrm{C}$ and E. coli JM089 in TSA at $37^{\circ} \mathrm{C}$ for $24 \mathrm{~h}$ prior to the experiments.

\section{Bacterial autoagglutination assay}

Cell autoagglutination ability was detected as described by Gogra et al. [15]. Briefly, the cultured shaking medium was vortexed and allowed to stand at room temperature for $2 \mathrm{~h}$. Changes in absorbance were monitored at $600 \mathrm{~nm}$ using the microtiter plate reader Infinite 200 (Tecan, Switzerland) by taking the upper culture medium into a 96well polystyrene flat plate. Autoagglutination ability was determined as percent autoagglutination $(\% \mathrm{AAg})$ using the formula \%AAg $=\left[1-\left(\mathrm{A}_{2} /\right.\right.$ $\left.\left.A_{0}\right)\right] \times 100$, where $A_{0}$ and $A_{2}$ were the absorbencies of the cultured media at 0 and $2 \mathrm{~h}$ intervals, respectively. Strains with \%AAg $\geq 70 \%, 50-70 \%$ and $<50 \%$ were arbitrarily designated as high, moderate and low autoagglutination, respectively.

\section{Salt aggregation test}

Bacterial suspensions and ammonium sulfate $\left(\mathrm{NH}_{4}\right)_{2} \mathrm{SO}_{4}$ solutions used in the Salt Aggregation Test (SAT) were prepared in phosphate buffered saline (PBS, pH6.8). Molarities of ammonium sulfate ranged from 4.0 to $0.002 \mathrm{~mol} \mathrm{l}^{-1}$ [9]. The SAT value was recorded as the lowest molarity of ammonium sulfate giving visible bacterial aggregation when evaluating bacterial cell surface hydrophobicity. Strains with SAT values $>4.0 \mathrm{~mol} \mathrm{l}^{-1}, 2.0-4.0 \mathrm{~mol} \mathrm{l}^{-1}, 1.0-2.0 \mathrm{~mol} \mathrm{l}^{-1}$ and $0.0-1.0 \mathrm{~mol} \mathrm{l}^{-1}$ were designated as no, low, moderate and high hydrophobicity, respectively.

\section{Microbial adhesion to hydrocarbons (MATH) assay}

MATH assay was performed with hydrophobic hydrocarbon nhexadecane (Sigma, purity $>99 \%$ ). The adherence was measured by recording the absorbance changes (classical spectrophotometer MATH assay, SPE) [16] at $600 \mathrm{~nm}$, by counting bacterial cell number changes with haemocytometer (modified microscope MATH assay, MIC) [13] or by counting CFU in ST plate (TSA medium supplemented with $2 \%$ $\mathrm{NaCl})$. For the modified CFU MATH assay, the bacterial concentration was evaluated by CFU instead of measuring absorbance or counting bacterial cells under the microscope. The fraction partitioned to the hydrocarbon phase (\%Adh) was calculated as: \%Adh $=\left[1-\mathrm{C}_{\text {aqueous phase }}{ }^{\prime}\right.$ $\left.\mathrm{C}_{\text {original bacterial suspension }}\right] \times 100$, where $\mathrm{C}$ means the absorbance $\left(\mathrm{OD}_{600}\right)$ or bacterial cell number (cell ml-1) or CFU ml-1 of the suspension. Strains with $\%$ Adh $\geq 70 \%, 50-70 \%$ and $<50 \%$ were arbitrarily classified as high, moderate and low hydrophobicity, respectively. All tests were repeated three times.

\section{Slime layer production assay}

Qualitative detection of slime layer production was studied by culturing strains on Congo Red Agar plates (CRA) [17]. All strains were inoculated onto the surface of CRA plates, incubated at $27^{\circ} \mathrm{C}$ for $24 \mathrm{~h}$ and then incubated overnight at room temperature [18]. The bacteria producing slime layer appeared as black colonies, whereas non-slime producers remained non-pigment [19].

\section{Biofilm production assay}

Biofilm production was assessed on polystyrene microtiter plates as described by Stepanovic et al. [20,21]. The biomass of biofilm was quantified by measuring the absorbance of the solubilized dye at 570 $\mathrm{nm}$. The optical density (ODs) obtained by the mean of the absorbance from nine wells of three times was compared with the absorbance of negative controls (ODnc), ODnc $=$ average $\mathrm{OD}_{570}$ of negative control $+(3 \times$ SD of negative control). Final ODs value of the assayed strain was expressed as average $\mathrm{OD}_{570}$ value of the strain reduced by ODnc value $\left(\mathrm{ODs}=\right.$ average $\mathrm{OD}_{570}$ of a strain $\left.-\mathrm{ODnc}\right)$. $\mathrm{ODnc}$ value was calculated for each microtiter plate separately. The levels of biofilm production were defined as: ODs $\leq$ ODnc, no; ODnc < ODs $\leq$ 2ODnc, weak; 2ODnc < ODs $\leq 4$ ODnc, moderate; and ODs $>$ 4ODnc, strong biofilm

\begin{tabular}{|c|c|c|c|c|c|c|c|}
\hline \multirow{2}{*}{ Characteristics } & \multirow{2}{*}{\multicolumn{2}{|c|}{ Characteristics }} & \\
\hline & & & \multicolumn{5}{|c|}{ CECT 4638} \\
\hline \multicolumn{8}{|l|}{ Adhesion } \\
\hline \multirow{5}{*}{ Hydrophobicity } & \multicolumn{2}{|c|}{ Autoagglutination (\%) } & $29.6 \pm 5.7(\mathrm{~L})$ & $10.5 \pm 4.8(\mathrm{~L})$ & $1.36 \pm 1.2(\mathrm{~L})$ & $4.3 \pm 3.5(\mathrm{~L})$ & $22.9 \pm 8.3(\mathrm{~L})$ \\
\hline & SAT $\left(\mathrm{mol} \mathrm{l}^{-1}\right)$ & & $0.2(\mathrm{~S})$ & $0.9(\mathrm{~S})$ & $0.9(\mathrm{~S})$ & $0.9(\mathrm{~S})$ & $0.9(\mathrm{~S})$ \\
\hline & \multirow{3}{*}{$\begin{array}{l}\text { MATH } \\
\text { (\% partition) }\end{array}$} & SPE & $47.3 \pm 1.4(\mathrm{~L})$ & $-1.1 \pm 6.1(\mathrm{~L})$ & $-42.2 \pm 6.2(\mathrm{~L})$ & $-71.1 \pm 2.9(\mathrm{~L})$ & $-74.9 \pm 3.5(L)$ \\
\hline & & MIC & $23.4 \pm 6.9(\mathrm{~L})$ & $19.2 \pm 6.1(\mathrm{~L})$ & $36.7 \pm 19.1(L)$ & $26.3 \pm 19.4(\mathrm{~L})$ & $32.5 \pm 10.8(\mathrm{~L})$ \\
\hline & & CFU & $56.7 \pm 3.2(\mathrm{M})$ & $81.9 \pm 2.3(\mathrm{~S})$ & $82.5 \pm 2.6(\mathrm{~S})$ & $79.5 \pm 2.6(\mathrm{~S})$ & $51.9 \pm 3.1(\mathrm{M})$ \\
\hline \multicolumn{3}{|l|}{ Slime layer } & + & + & + & + & - \\
\hline \multicolumn{3}{|c|}{ Biofilm production $\left(\mathrm{OD}_{570}\right)$} & $1.23 \pm 0.14$ & $1.20 \pm 0.41$ & $1.12 \pm 0.24$ & $1.09 \pm 0.18$ & Overflow \\
\hline \multicolumn{8}{|l|}{ Motility } \\
\hline \multicolumn{3}{|l|}{ Swimming $(\mathrm{mm})$} & $9.0 \pm 0.3(+)$ & $5.6 \pm 1.0(+)$ & $3.3 \pm 0.6(+)$ & $4.1 \pm 0.6(+)$ & \multirow{3}{*}{ ND } \\
\hline \multicolumn{3}{|l|}{ Swarming } & - & - & - & - & \\
\hline \multicolumn{3}{|l|}{ Twitching } & ++ & + & + & + & \\
\hline \multicolumn{3}{|c|}{ MIC (norfloxacin) $\left(\mu \mathrm{g} \mathrm{ml}^{-1}\right)$} & 10.1 & 2.0 & 2.0 & 2.0 & \multirow{2}{*}{ ND } \\
\hline \multicolumn{3}{|c|}{ MBC (norfloxacin) $\left(\mu \mathrm{g} \mathrm{ml}^{-1}\right)$} & 16.9 & 16.9 & 16.9 & 16.9 & \\
\hline
\end{tabular}

SAT: Salt Aggregation Test; MATH: Microbial Adhesion to Hydrocarbons; SPE: Spectrophotometer; Mic: Microscope; CFU: Colony Forming Unit; MIC: Minimum Inhibitory Concentration; MBC: Minimum Bactericidal Concentration; L: Low; M: Moderate; S: Strong; ND: Not Done; +: Positive; ++: Strong Positive; -: Negative; Data are expressed as mean $\pm \mathrm{SD}$.

Table 1: Characteristics of live cells of Vibrio scophthalm. 
Citation: Qiao G, Li H, Xu DH, II Park S (2012) Modified a Colony Forming Unit Microbial Adherence to Hydrocarbons Assay and Evaluated Cell Surface Hydrophobicity and Biofilm Production of Vibrio scophthalmi. J Bacteriol Parasitol 3:130 doi:10.4172/2155-9597.1000130

Page 3 of 6

production. The optimal biofilm production conditions including incubation time, culture media, $\mathrm{NaCl}$ and glucose concentrations, were determined.

\section{Motility assay}

Swimming: Tryptone swimming plates were made up of $1 \%$ tryptone, $0.5 \% \mathrm{NaCl}$ and $0.3 \%$ agar. Plates were inoculated with a bacterial colony with a sterile toothpick and plates were incubated at $25^{\circ} \mathrm{C}$ for $18 \mathrm{~h}$. Motility was then assessed qualitatively by examining the circular turbid zone formed by the bacterial cells migrating away from the point of inoculation.

Swarming: Swarming plates were composed of $0.5 \%$ Bacto Agar and $8 \mathrm{~g}$ of nutrient broth/liter (both from Difco, Mich.) supplemented with $0.5 \%$ glucose $(\mathrm{w}: \mathrm{v})$ and $2 \% \mathrm{NaCl}$ and dried at room temperature overnight [22]. Plates were inoculated with a sterile toothpick and the plates were incubated at $25^{\circ} \mathrm{C}$ for $24 \mathrm{~h}$.

Twitching: Plates were stabbed with a toothpick through a thin (approximately $3 \mathrm{~mm}$ ) LB agar layer (1\% agar) to the bottom of the petri dish. After incubation at $25^{\circ} \mathrm{C}$ for $24 \mathrm{~h}$, a zone of growth at the interface between the agar and the polystyrene surface was observed [23]. The ability of bacteria to adhere and form a biofilm on the polystyrene surface was examined by removing the agar, washing unattached cells and then staining the attached cells with $1 \%$ crystal violet solution ( w:v) for $15 \mathrm{~min}$ and washing with water until colorless.

\section{Determination of multiple antibiotic resistances}

The assay was conducted using the disk-diffusion technique of $\mathrm{Na}$ tional Committee for Clinical Laboratory Standard [24]. The antibiotics and concentrations were listed in Table 2. According to antibiotic resistance assay, all strains were sensitive to norfloxacin. To further demonstrate the antibiotic susceptibility of these strains with different biofilm production, the Minimum Inhibitory Concentration (MIC) and Minimum Bactericidal Concentration (MBC) of norfloxacin against these strains were evaluated separately. MIC was recorded as the minimum concentration of norfloxacin at which microbial growth was inhibited and MBC determined after cultured on Mueller Hinton Agar (MHA, Difco) at $27^{\circ} \mathrm{C}$ for $48 \mathrm{~h}$.

\section{Results}

\section{Bacterial autoagglutination ability}

The percent autoagglutination of 4 strains (V. scophthalmi A19008, A19010, CECT 4638, CAIM 1797 and E. coli JM089) were 29.6, 10.5, $1.3,4.3$ and $22.9 \%$, respectively (Table 1 ). All strains showed low autoagglutination ability.

\section{SAT value}

SAT values of strain $V$. scophthalmi A19008, A19010, CECT 4638 CAIM 1797 and E. coli JM089 were 0.2, 0.9, 0.9, 0.9 and $0.9 \mathrm{~mol} \mathrm{l}^{-1}$ (Table 1), showing strong positive cell surface hydrophobicity.

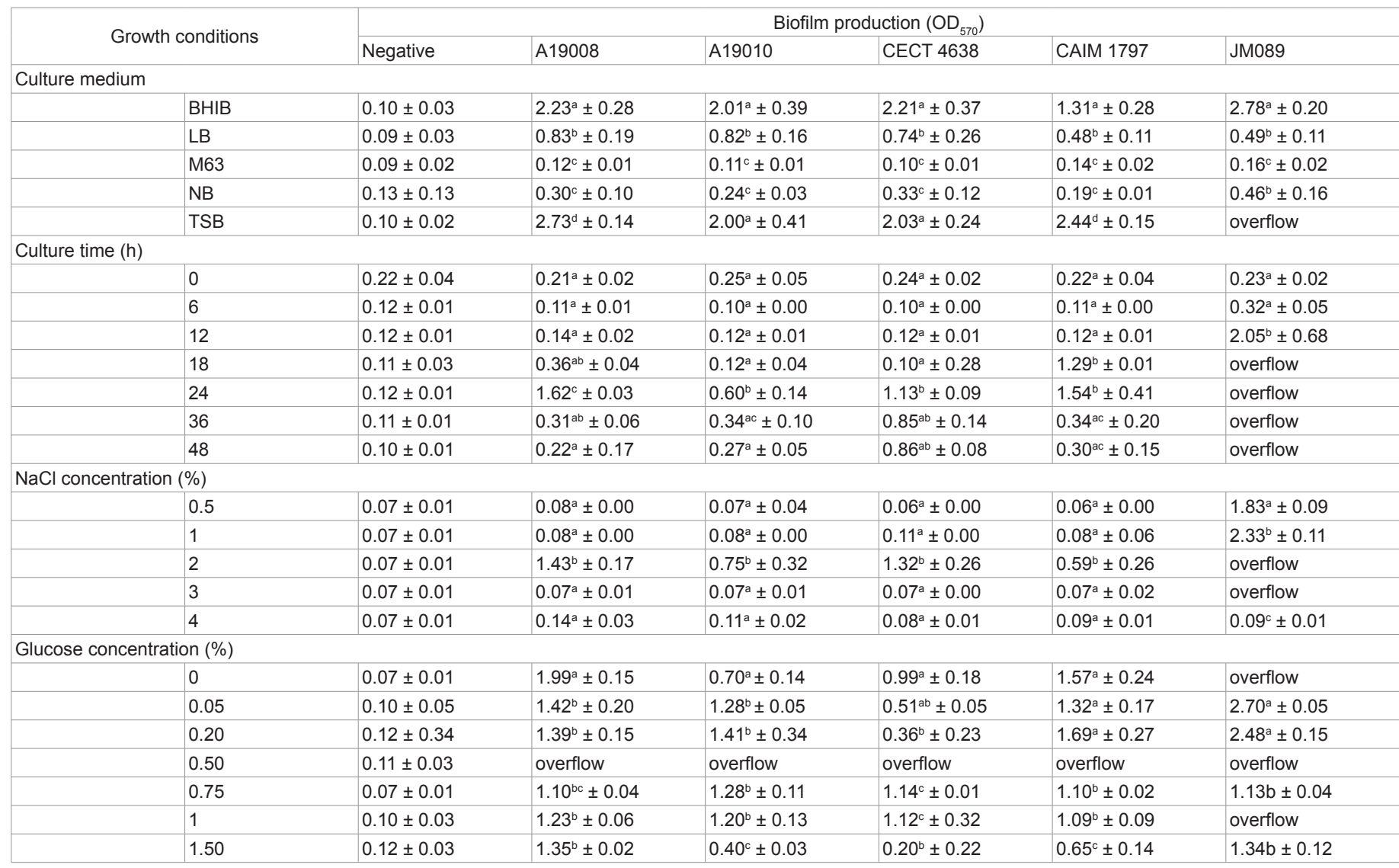

BHIB: Brain-Heart Infusion Broth (BBL, USA); LB: Luria-Bertani broth; M63 was made as follows: $68 \mathrm{~g} \mathrm{l}^{-1} \mathrm{KH}_{2} \mathrm{PO}_{4}, 10 \mathrm{~g} \mathrm{l}^{-1}\left(\mathrm{NH}_{4}\right)_{2} \mathrm{SO}_{4}, 0.246 \mathrm{gl}^{-1} \mathrm{MgSO}_{4} \cdot 7 \mathrm{H}_{2} \mathrm{O}, 2.5 \mathrm{mg} \mathrm{l}^{-1}$ $\mathrm{FeSO}_{4} \cdot 7 \mathrm{H}_{2} \mathrm{O}, 2 \mathrm{~g} \mathrm{l}^{-1} \mathrm{D}$-glucose; NB: Nitrate Broth (Difco, USA); TSB: Tryptic Soy Broth (Bacto, USA). All the above media were supplemented with final $2 \%$ NaCl. Data are expressed as mean \pm SD. abcd Means in the same strain with different superscript are significantly different $(p<0.05)$ between growth conditions for one treatment $(e . g$ medium). 
Citation: Qiao G, Li H, Xu DH, II Park S (2012) Modified a Colony Forming Unit Microbial Adherence to Hydrocarbons Assay and Evaluated Cell Surface Hydrophobicity and Biofilm Production of Vibrio scophthalmi. J Bacteriol Parasitol 3:130 doi:10.4172/2155-9597.1000130

\section{MATH assay}

Classical SPE MATH assay: Fraction partitioned to hydrocarbon (\%Adh) was 47.3\% for V. scophthalmi A19008, -1.1\% for A19010, $-42.2 \%$ for CECT $4638,-71.1 \%$ for CAIM 1797 and $-74.9 \%$ for E. coli JM089, respectively (Table 1).

Modified MIC MATH assay: The \%Adhs for V. scophthalmi A19008, A19010, CECT 4638, CAIM 1797 and E. coli JM089 were $23.4 \%, 19.2 \%, 36.7 \%, 26.3 \%$ and $32.5 \%$, respectively (Table 1 ). The \%Adh obtained from the modified MIC MATH assay was higher than that by classical SPE MATH method.

Modified CFU MATH assay: Although bacterial cells were counted under a microscope, it was difficult to obtain accurate counts since bacterial cells moved rapidly. To avoid the erroneous effect caused by hydrocarbon droplets in the classical SPE MATH assay and by the motility of bacterial cells in the modified MIC MATH assay, the modified CFU MATH assay was used for directly counting of non-adhered bac- teria through plate culture. The \%Adh in CFU MATH assay was significantly higher than the former two MATH assays. The \%Adhs of 5 strains V. scophthalmi A19008, A19010, CECT 4638, CAIM 1797 and E. coli JM089 was $56.7 \%, 81.9 \%, 82.5 \%, 79.5 \%$ and $51.9 \%$, respectively (Table 1).

\section{Comparison of different methods for assessing hydrophobicity}

Hydrophobicity depended considerably on the method used. For example, V. scophthalmi A19008 showed strong hydrophobicity using the SAT assay, low hydrophobicity using the classical SPE and modified MIC MATH assays and moderate hydrophobicity when using the modified CUF MATH assay. In order to find why results were different, the bacterial suspension was observed under the microscope after mixing with hexadecane. A microscopic image of a suspension containing droplets placed on a glass slide was shown in Figure 1. The image demonstrated: (i) hydrocarbon droplets and bacterial cells could be easily distinguished (Figure1A and B); (ii) droplets appeared in the aqueous bacterial suspension (Figure 1A); (iii) bacteria appeared in the upper

\begin{tabular}{|c|c|c|c|c|}
\hline \multirow{2}{*}{ Antibiotics (content: $\mu \mathrm{g} \mathrm{slip}{ }^{-1}$ ) } & \multicolumn{4}{|c|}{ Diameter of inhibiting ring (mm) (antibacterial activity) } \\
\hline & A19008 & A19010 & CECT 4638 & CAIM 1797 \\
\hline Tetracycline (30) & $21.0(\mathrm{~S})$ & $34.5(\mathrm{~S})$ & $47.2(\mathrm{~S})$ & $19.0(\mathrm{~S})$ \\
\hline Oxytetracycline (30) & $22.3(\mathrm{~S})$ & $34.6(\mathrm{~S})$ & $32.3(\mathrm{~S})$ & $22.1(\mathrm{~S})$ \\
\hline Doxycycline (30) & $18.3(\mathrm{~S})$ & $32.0(\mathrm{~S})$ & $32.1(\mathrm{~S})$ & $24.5(S)$ \\
\hline Kanamycin (30) & $13.5(\mathrm{R})$ & $20.0(S)$ & $14.0(\mathrm{I})$ & $14.1(\mathrm{I})$ \\
\hline Gentamycin (10) & $14.6(\mathrm{I})$ & $21.0(\mathrm{~S})$ & $22.1(\mathrm{~S})$ & $12.1(\mathrm{I})$ \\
\hline Norfloxacin (10) & $21.3(\mathrm{~S})$ & $27.4(S)$ & $14.2(\mathrm{I})$ & $14.2(\mathrm{I})$ \\
\hline Nalidixic acid (30) & $12.0(\mathrm{R})$ & $18.9(\mathrm{I})$ & $35.7(\mathrm{~S})$ & $18.1(\mathrm{I})$ \\
\hline Ciprofloxacin (5) & $18.8(\mathrm{I})$ & $22.3(\mathrm{~S})$ & $28.7(\mathrm{~S})$ & $15.0(\mathrm{I})$ \\
\hline Oxacillin (1) & $7.4(\mathrm{R})$ & $7.5(\mathrm{R})$ & $8.1(\mathrm{R})$ & $7.9(\mathrm{R})$ \\
\hline Ampicillin (10) & $20.5(R)$ & $31.2(\mathrm{~S})$ & $27.9(\mathrm{I})$ & $23.1(\mathrm{I})$ \\
\hline Amoxicillin (30) & $22.1(\mathrm{~S})$ & $25.3(\mathrm{~S})$ & $30.5(\mathrm{~S})$ & $19.2(\mathrm{~S})$ \\
\hline Erythromycin (15) & $15.2(\mathrm{I})$ & $18.0(\mathrm{I})$ & $22.2(\mathrm{I})$ & $15.0(\mathrm{I})$ \\
\hline Sulfisoxazol (25) & $20.3(S)$ & $30.1(\mathrm{~S})$ & $34.1(\mathrm{~S})$ & $9.1(\mathrm{R})$ \\
\hline Enrofloxacin (5) & $15.9(\mathrm{I})$ & $32.1(\mathrm{~S})$ & $39.1(\mathrm{~S})$ & $15.0(\mathrm{~S})$ \\
\hline Chloramphenicol (30) & $24.0(\mathrm{~S})$ & $34.1(\mathrm{~S})$ & $45.1(\mathrm{~S})$ & $21.0(\mathrm{~S})$ \\
\hline Nitrofurantoin (300) & $19.2(\mathrm{~S})$ & $23.1(\mathrm{~S})$ & $34.1(\mathrm{~S})$ & $14.1(\mathrm{I})$ \\
\hline Novobiocin (5) & $10.7(\mathrm{R})$ & $24.2(\mathrm{~S})$ & $34.2(\mathrm{~S})$ & $18.0(\mathrm{I})$ \\
\hline
\end{tabular}

S: Sensitive; I: Intermediate; R: Resistant

Table 3: Results of antibiotics susceptibility of Vibrio scophthalmi.
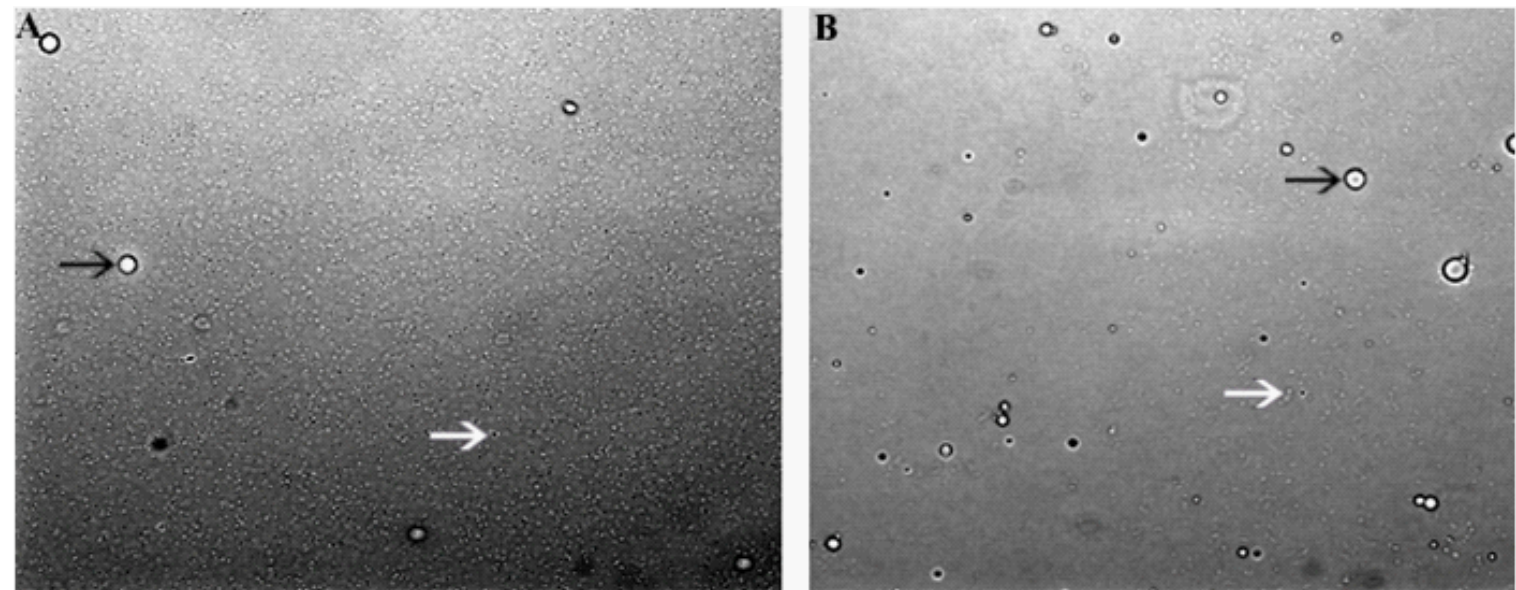

Figure 1: Microscope images of hydrocarbon droplets (× 400). A: microscope image of hydrocarbon droplets stabilized in the aqueous bacterial suspension placed on the glass slide; B: microscope image of hydrocarbon droplets stabilized in upper hexadecane. White arrows point to bacterial cells; Black arrows point to hydrocarbon droplet. 
hexadecane phase (Figure 1B). This explained why the absorbance in the aqueous bacterial suspension increased and minus \%Adh was obtained in the classical SPE MATH assay. Based on the fast motility of Vibrio species, it is difficult to get an accurate count in the modified MIC MATH assay. This study exploited the modified CFU MATH assay and directly counted non-adhered bacteria through plate culture. Since V. scophthalmi A19008 showed moderate positive hydrophobicity in both SAT and MATH assay, V. scophthalmi A19008 was considered as moderate positive hydrophobicity and other 3 strains as strong positive hydrophobicity.

\section{Determination of slime layer production}

Strains of V. scophthalmi (A19008, A19010, CECT 4638 and CAIM 1797) formed black colonies on CRA plates, whereas, E. coli JM089 could not form slime layer.

\section{Biofilm production}

The absorbances of strain V. scophthalmi A19008, A19010, CECT 4638, CAIM 1797 and E. coli JM089 were 1.23, 1.20, 1.12, 1.09 and overflow, respectively after incubation in TSB supplemented with final $2 \% \mathrm{NaCl}$ and $1 \% \mathrm{D}$-glucose for $24 \mathrm{~h}$, suggesting strong biofilm production (Table 1). Moreover, the incubation time, culture media, $\mathrm{NaCl}$ and glucose concentrations were evaluated to see their effects on the biofilm production. The optimal biofilm production conditions for $V$. scophthalmi were: BHIB or TSB media supplemented with $2 \% \mathrm{NaCl}$ and $0-0.5 \%$ glucose and incubation for $24 \mathrm{~h}$ (Table 2).

\section{Motility}

All strains of $V$. scophthalmi were motile with swimming and twisting, no swarming.

\section{Antibiotics susceptibility}

All strains of $V$. scophthalmi were sensitive to tetracycline, oxytetracycline, doxycycline, minocycline, amoxicillin and chloramphenicol, resistant to oxacillin. Strain A19008 was resistant to kanamycin, nalidixic acid, ampicillin and novobiocin, but another 3 strains showed different susceptibility (intermediate or sensitive) (Table 3). The MIC of strain A19008, A19010, CECT 4638 and CAIM 1797 to norfloxacin was $10.1,2.0,2.0$ and $2.0 \mu \mathrm{g} \mathrm{ml}^{-1}$, respectively. The $\mathrm{MBC}$ was the same with $16.9 \mu \mathrm{g} \mathrm{ml}^{-1}$ for all strains.

\section{Discussion}

The bacterial adhesion to the external surfaces and tissues of a host is an essential initial step in the infection of a host and subsequent occurrence of disease [25]. It is widely accepted that hydrophobicity and biofilm production are major factors in the adhesive process and survival of pathogens in cells [14]. Hydrophobic microorganisms are capable of adhering to the oil/water interface and utilizing oil components as a source of energy for growth and metabolism [26]. Lee and Yii [27] noted that a single assay could not be regarded as a reliable indication of the surface hydrophobicity for different bacterial isolates. It will be considered as positive hydrophobicity when a bacterial isolate shows moderate positive hydrophobicity in both SAT and BATH assays. In this study, the tested strains exhibited moderate to strong hydrophobicity as determined by both SAT and MATH assays. It demonstrated V. scophthalmi potential ability to adhere to host external surfaces and tissues during the infection process. The SAT was first developed as a rapid and simple procedure to quantify bacterial cell surface hydrophobicity [28]. Later, a MATH had been developed on the base of the binding of hexadecane to bacteria [16]. In this study, MATH assays were conduct- ed using three methods, classical SPE MATH, modified MIC MATH [13] and modified CFU MATH (this study). The \%Adh obtained in the modified CFU MATH assay was higher than that by the other two methods. The \% Adh using the classical SPE method sometimes showed minus value as a result of the inevitable droplets on the absorbance after mixing and phase separation. In hydrophilic solution after mixing and phase separation, the bacterial cells adhering to hydrocarbon droplets rose to the oil/water interface so the cell concentration in the lower aqueous bacterial suspension was expected to decrease after separation into two phases. The negative \%Adh was also reported by Zoueki et al. [13]. To avoid the erroneous effect caused by droplets in classical SPE MATH assay, modified MIC MATH assay was employed and the bacterial cells were counted directly through hemocytometer under the microscope [13]. Although bacterial cell can be easily distinguished from hydrocarbon droplets in this method, the experimental results are sometimes unstable, especially for the bacteria with active motility. In this study, bacterial cells of the assayed strains were motile with swimming and moved quickly under the microscope, which resulted in the inaccurate enumeration with the higher standard deviation in the triplicate samples. To avoid the inaccuracy and time consumption in the MIC MATH assay, a modified CFU MATH assay was developed and used for this study. The results from the CFU MATH assay were similar to it in the SAT assay with a considerable lower standard deviation. In addition, biofilm is another determining factor in the adhesion and survival of pathogens in hosts [14]. Organisms within biofilm can withstand nutrient deprivation, $\mathrm{pH}$ changes, oxygen radicals, disinfectants and antibiotics better than planktonic organisms [29]. Biofilm production has been known as one of the virulent factors of $V$. harveyi [30]. Won and Park [30] assayed the eight strains of $V$. harveyi and found that the most virulent strain FR-2 exhibited highest biofilm production. In this study, strain A19008 showed the highest value of biofilm production among all tested strains of $V$. scophthalmi and was most virulent to olive flounder (personal communication). The initial attachment and development of the biofilm production requires some bacterial movements or surface structures such as flagella-mediated swimming, swarming or competition/virulence factors such as type IV pilus-based twitching motility [31]. This study investigated three types of motilities and found that V. scophthalmi moved with swimming and twitching. Among strains investigated in this study, strain A19008 showed the highest level of motilities. The biofilm production was related with competition/virulence factors. The biofilm production is influenced by environmental conditions and bacterial challenges [32]. In the present study, we evaluated the effect of incubation time, growth media, $\mathrm{NaCl}$ and glucose concentrations on biofilm production. The BHIB or TBS media supplemented with $2 \% \mathrm{NaCl}$ and $0.05-0.5 \% \mathrm{D}$-glucose were the most suitable conditions for biofilm production. Biofilm are proved to be associated with the high levels of tolerance to prolong antibiotic therapy in human and veterinary infections [33]. This study surveyed the antibiotic sensitivity of the tested strains and demonstrated that strain A19008 was the highest biofilm producer and more resistance to antibiotics. Furthermore, MIC and MBC of strain A19008 against norfloxacin were also higher. The pathogens with strong resistance to antibiotics are better for the adhesion, survival and infection. Slime layer production is related with the biofilm production [29] and considered as one of the virulence properties of Aeromonas spp. [34,35].

In conclusion, this study modified a MATH assay using CFU method and evaluated the adhesion of V. scophthalmi on the cell surface hydrophobicity. The modified CFU MATH assay will be recommended for the fast motile bacteria due to its accurate results and it is easily conducted. V. scophthalmi showed moderate/high cell surface hydro- 
Citation: Qiao G, Li H, Xu DH, II Park S (2012) Modified a Colony Forming Unit Microbial Adherence to Hydrocarbons Assay and Evaluated Cell Surface Hydrophobicity and Biofilm Production of Vibrio scophthalmi. J Bacteriol Parasitol 3:130 doi:10.4172/2155-9597.1000130

Page 6 of 6

phobicity and biofilm production and demonstrated its possibility for adhesion to host surfaces. The level of biofilm production is related to the pathogenicity of $V$. scophthalmi and antibiotics susceptibility, but other virulence factors in pathogenesis may also exist in the pathogenic bacteria.

\section{Acknowledgements}

This work was supported by the Pukyong National University Research Abroad Fund in 2009 (PS-2009-028).

\section{References}

1. Cerdà-Cuéllar M, Rosselló-Mora RA, Lalucat J, Jofre J, Blanch A (1997) Vibrio scophthalmi sp. nov., a new species from turbot (Scophthalmus maximus). Int J Syst Bacteriol 47: 58-61.

2. Jo MR, Kim MC, Song CB (2006) Development of a rapid diagnosis kit for Vibrios associated with the farmed olive flounder (Paralichthys olivaceus) in Jeju Island. J Fish Pathol F3.

3. Montes M, Farto R, Pérez MJ, Armadaa SP, Nieto TP (2006) Genotypic diversity of Vibrio isolates associated with turbot (Scophthalmus maximus) culture. Res Microbiol 157: 487-495.

4. Sugita $H$, Ito $Y$ (2006) Identification of intestinal bacteria from Japanese flounder (Paralichthys olivaceus) and their ability to digest chitin. Lett Appl Microbiol 43: 336-342.

5. Wang YG, Zhang Z, Qing L (2004) The main diseases of cultured turbot (Scophthalmus maximus) and their prevention and treatment. Marine Fisheries Research 25: 61-68.

6. Gristina AG, Costerton JW (1985) Bacterial adherence to biomaterials and tissue. The significance of its role in clinical sepsis. J Bone Joint Surg Am 67: 264-273

7. Ascencio F, Johansson G, Wadström T (1995) Cell surface charge and cell surface hydrophobicity of collagen binding Aeromonas and Vibrio strains. Arch Microbiol 164: 223-230

8. Rosenberg M, Doyle RJ (1990) Microbial cell surface hydrophobicity: history, measurement, and significance. American Society for Microbiology, Washington, DC.

9. Ljungh A, Hjerte'n S, Wadstro"n T (1985) High surface hydrophobicity of autoaggregating Staphylococcus aureus strains isolated from human infections studied with the salt aggregation test. Infect Immun 47: 522-526.

10. Rosenberg M, Gutnick D, Rosenberg E, Rosenberg M, Gutnick D, et al. (1980) Adherence of bacteria to hydrocarbons: a simple method for measuring cell surface hydrophobicity. FEMS Microbiol Lett 9: 29-33.

11. van der Mei HC, van de Belt-Gritter B, Busscher HJ (1995) Implications of microbial adhesion to hydrocarbons for evaluating cell surface hydrophobicity. 2. Adhesion mechanisms. Colloids and Surfaces B: Biointerfaces 5: 117-126.

12. van der Mei HC, Weerkamp AH, Busscher HJ (1987) A comparison of various methods to determine hydrophobic properties of streptococcal cell surfaces. J Microbiol Meth 6: 277-287.

13. Zoueki CW, Tufenkji N, Ghoshal S (2010) A modified microbial adhesion to hydrocarbons assay to account for the presence of hydrocarbon droplets. J Colloid Interface Sci 344: 492-496.

14. Daly JG, Stevenson RMW (1987) Hydrophobic and haemagglutination properties of Renibacterium salmoninarum. J Gen Microbiol 133: 3575-3580.

15. Gogra AB, Yao J, Sandy EH, Zheng SX, Zaray G, et al. (2010) Cell surface hydrophobicity (CSH) of Escherichia coli, Staphylococcus aureus and Aspergillus niger and the biodegradation of Diethyl Phthalate (DEP) via Microcalorimetry. J Am Sci 6: 78-88.

16. Rosenberg M (1981) Bacterial adherence to polystyrene. A replica method for screening for bacterial hydrophobicity. Appl Env Microbiol 42: 375-377.

17. Freeman DJ, Falkiner FR, Keane CT (1989) New method for detecting slime production by coagulase negative Staphylococci. J Clinic Pathol 42: 872-874.

18. Chaieb K, Chehab O, Zmantar T, Rouabhia M, Mahdouani K, et al. (2007) In vitro effect of $\mathrm{pH}$ and ethanol on biofilm formation by clinical ica-positive Staphylococcus epidermidis strains. Ann Microbiol 57: 431-437.
19. Subashkumar R, Thayumanavan T, Vivekanandhan G, Perumalsamy L (2006) Occurrence of Aeromonas hydrophila in acute gasteroenteritis among children. Indian J Med Res 123: 61-66.

20. Stepanovic S, Irkovic IC, Ranin L, Svabić-Vlahovic M (2004) Biofilm formation by Salmonella spp. and Listeria monocytogenes on plastic surface. Lett Appl Microbiol 38: 428-432.

21. Stepanovic S, Vukovic D, Dakic I, Savic B, Svabić-Vlahovic M (2000) A modified microtiter-plate test for quantification of staphylococcal biofilm formation. $J$ Microbiol Meth 40: 175-179.

22. Rashid MH, Kornberg A (2000) Inorganic polyphosphate is needed for swimming, swarming, and twitching motilities of Pseudomonas aeruginosa. Proc Natl Acad Sci USA 97: 4885-4890.

23. Darzins A (1993) The pilG gene product, required for Pseudomonas aeruginosa pilus production and twitching motility, is homologous to the enteric single-domain response regulator Che Y. J Bacteriol 175: 5934-5944.

24. NCCLS (2004) Performance standards for antimicrobial disk susceptibility testing. Fourteenth informational supplement. NCCLS, Wayne, Pennsylvania.

25. Montgomery MT, Kirchman DL (1994) Induction of chitin-binding proteins during the specific attachment of the marine bacterium Vibrio harveyi to chitin. App Environ Microbiol 60: 4284-4288.

26. Marshall KC (1991) The importance of studying microbial cell surfactants. (1stedn), Wiley VCH Publishers, New York.

27. Lee KK, Yii KC (1996) A comparison of three methods for assaying hydrophobicity of pathogenic Vibrios. Lett Appl Microbiol 23: 343-346.

28. Lindahl M, Faris A, Wadström T, Hjertén S (1981) A new test based on "salting out" to measure relative surface hydrophobicity of bacterial cells. Biochimica et Biophysica Acta 77: 471-476.

29. Karima B, Fethi BA, Ali E, Amina B (2011) Adherence assays and slime production of Staphylococcus aureus strains after their incubation in seawater microcosms. Ann Microbiol 4: 819-823.

30. Won KM, Park SI (2008) Pathogenicity of Vibrio harveyi to cultured marine fishes in Korea. Aquaculture 285: 8-13.

31. Deziel E, Comeau Y, Villemur R (2001) Initiation of biofilm formation by Pseudomonas aeruginosa 57RP correlated with emergence of hyperpiliated and highly adherent phenotypic variants deficient in swimming, swarming and twitching motilities. J Bacteriol 183: 1195-1204.

32. Rob VH, Michiels CW (2005) Role of bacterial cell surface structures in Escherichia coli biofilm formation. Res Microbiol 156: 626-633

33. Hoyle BD, Costerton WJ (1991) Bacterial resistance to antibiotics: The role of biofilms. Prog Drug Res 37: 91-105.

34. Rathinasamy S, Thangavelu T, Govindhasamy V, Perumalsamy L (2006) Occurrence of Aeromonas hydrophila in acute gasteroenteritis among children. Indian J Med Res 123: 61-66.

35. Sechi LA, Deriu A, Falchi MP, Fadda G, Zanetti S (2002) Distribution of virulence genes in Aeromonas spp. isolated from Sardinian waters and from patients with diarrhoea. J Appl Microbiol 92: 221-227. 